\title{
PROMOTING TOTAL PHYSICAL RESPONSE (TPR) FOR YOUNG LEARNERS IN ENGLISH CLASS
}

\author{
Atik Rokhayani \\ atik.rokhayani@umk.ac.id \\ English Education Department, Universitas Muria Kudus
}

\begin{abstract}
Nowadays, the teaching English for young learners is getting attention from many people. In Indonesia, English lessons taught to students from early childhood to university level. In the early childhood level, learning English is taught simply that children are interested and do not get bored in learning. The role of teachers is very influential to the success of learning in the classroom. English teachers must be able to select and apply learning techniques which are appropriate to the needs of their students. One of the techniques that can be applied to children is Total Physical Response (TPR). The study aims to describe the use of TPR technique for children in early childhood. The writer of the study explores the use of TPR in teaching and learning English. The research method is descriptive qualitative. The writer describes the activities carried out by teachers and students in using TPR. The results of the activities in the classroom showed that the TPR effectively applied to children because they enjoy learning English. Children are also very active in learning English. The writer hopes that the study contributes to the activities of teaching and learning English, especially teaching English for young learners. The writer also suggests that TPR can be applied by the teachers to teach young learners.
\end{abstract}

Key words: Total Physical Response (TPR), English for Young Learners

\section{INTRODUCTION}

Nowadays, English is very important for young learners. Teaching English for young learners is increasingly popular around the world (Butler, 2015). In many countries, English is given to young learners. Young learners are tend to be active students in the classroom. In English class, the young learners have to take a big role in learning English. They are the main actors and actresses in the class. So, the teachers have to create an active and interactive English class. They need a good class management. Some teachers considered that teaching English for young learners is difficult to do. They have to cope with the students' needs and characters. The teachers may guide and affect the English teaching and learning process. They cannot dominate the class that makes the students uncomfortable in the class. In addition, the learning atmosphere needs to be arranged to be better so both the students and the teachers enjoy in the teaching and learning process.

The teachers should be able to manage the class well. Many experts reveal that the use of appropriate techniques used by the teachers can attract the young leaners in English classes. In the level of Play Group, the teachers must relax and fun in delivering the materials to children. In addition, teachers must create a good learning environment and appropriate instruction to students (Coltrane, 2003). Most of the teachers who are teaching English in Play Group are not from English Departments. This is a phenomenon that they do not have competence in teaching and learning of English. Therefore there are some teachers use English immersion and bilingual 
language in giving instruction to students (Barrow \& Markman-Pithers, 2016). From this situation, the writer focuses to conduct a research related to teaching English in the level of Play Group. In fact, English classes for children are an essential need for getting a new foreign language i.e. English.

Teaching English in the classroom should be in accordance with the interests and needs of students. Therefore, in teaching teachers should be relaxed and interesting. The use of appropriate techniques and media can create a comfortable atmosphere for the children. Besides that, the materials should also be considered well so that children do not feel bored in class. TPR (Total Physical Response) is one technique that can be applied to children. In the application of TPR, teachers act as a director and children as actors. TPR can be used as alternative teaching English as many experts agree that the TPR is effective for teaching young learners. In addition, TPR is one of the techniques that can simulate the children acquire the mother tongue naturally (Harrasi \& Sulaiman, 2014).

In English class, the teachers should be able to be experts who master classes so that children feel comfortable in learning. Teachers must have a pedagogical and professional competence so as to create a classroom atmosphere that appeals to children. Teachers should be able to guide the children in learning English. Teachers should as much as possible to use the Classroom English in the teaching and learning process to create an English atmosphere. The introduction of English from an early age can stimulate the young learners in acquiring a foreign language (English). So teachers should use simple and easy language to make the students understand.

In this study, the writer is interested in conducting research related to the teaching English. She focuses on the use TPR. This study describes the atmosphere of English learning at the level of the Play Group.

\section{LITERATURE REVIEW}

\section{English for Young Learners}

Young learners are the children who are in the age of five and ten or eleven years old (Scott \& Ytreberg, 1990). For some children, schools may be frightening for them. They just want to play and interact with their friends at school. Therefore, teachers must be able to make fun and enjoyable classroom. They also need to be able to invite children to participate in teaching activity. However there are some children who talk with their friends and play when the teachers are teaching. So, it is a big task for the teachers to conduct the English teaching and learning process.

Teaching English for young learners is a challenge for teachers because they should require more preparation and patience to create success in teaching. Good teachers are those who teach and their students are able to give a positive response to them. But actually the teacher is not the only source of learning for students. English teaching and learning between young learners and adults cannot be equated. This is reflected in the characteristics of adults and children are very different. There are some characteristics of children which are very talkative, having less concentration in teaching Play Group make the teachers must have the spirit of patience and high hospitality. Both the teacher and the students are the main element in the class. 
In teaching, the teachers need a new good technique or a way to teach English for the students (Hafidah, 2016). In English class of young learners, the teachers do not directly deliver the materials to the students because they still love to play so that in teaching and learning process, the teachers need some games or an interesting technique to the students. Besides, the movement is also very necessary given because children like to run so that teachers have to really focus on the development of the students. In addition, less concentration of children caused the teachers must have expertise in managing children to be better. According to some studies indicate that the activities conducted in the English teaching and learning process in young learners' class should be active and interesting for children. It is due to their characteristics that every child has different character. The students are unique. So, the teachers need to learn and understand the students' characteristics.

The learners of English are increasingly occurring in recent decade (Cheatham \& Ro, 2010). Learning English in the Play Group needs supports from many people especially students' parents. Parents should give full support to their children's education. A lot of parents want to provide the best education for their children. They are willing to sacrifice for their children's education. There are some parents who provide additional education to their children by providing courses though their children ages are still young. Based on this condition, the children need to have multiple intelligences that can build their characters.

\section{Total Physical Response (TPR)}

Total Physical Response originally developed by an American professor of psychology, James Asher. Total Physical Response is closely related to physical movement. It is considered as one of the teaching techniques which acquires students' mother tongue. It is based on the theory that the mother tongue acquisition in children can easily respond to parents' commands such as "take it" and "hold it". TPR is one of the techniques to teach a second language by listening and using physical action to comprehend a concept.

In the English teaching and learning process, the use of TPR involves movements that the students can actively do in the classroom. In teaching, the teachers can use a song or a storytelling in which there are commands to enable students to carry out instructions to perform an action. Teachers act as parents who instruct the message to their children. For example, the teacher says "jump". Then the teacher instructed the students to take this action then all the students jump. These activities can be done repeatedly. After that, the teacher asks the students to repeat the words as what they are doing. In the lessons, teachers can change the position of the class into a circle.

The advantages of using Total Physical Response in English teaching and learning activities:

1. Total Physical Response is fun, so many children enjoy in teaching and learning process

2. Total Physical Response can help the students remember English words and expressions

3. Total Physical Response can be applied in large and small class.

4. Total Physical Response is not only appropriate for young learners but also adult learners

5. Total Physical Response is suitable for active students in class 


\section{METHOD}

The study belongs to qualitative research. The writer describes the English teaching and learning process by using Total Physical response (TPR).

The writer used the implementation of Total Physical response (TPR) as the data in the research while she chose the students in one of the Play Group in Kudus Central Java, Indonesia.

The writer did the following steps in data collecting:

Discussing with the teachers related to the theory of TPR and the materials

Applying TPR in the activity of English class

In analyzing the data, the writer did the following steps:

1. Observing teaching and learning process in Play Group

2. Exploring the teachers and students activities

3. Presenting the result of the teachers and students activities in applying TPR

\section{FINDINGS AND DISCUSSION}

The students of Play Group are the students around the age of two to five years old. They are categorized as very young learners. They like playing much even in the class. So, the teachers in delivering the materials should be based on their needs. There are school facilities in Play Group, for example children toys, alphabet, cards, story books, playground etc. All of the students can enjoy the school facilities. Every child has different habit, so she/he may choose different school facilities. Related to English lesson, the teachers also put the pictures in the wall. Those pictures are usually written in English and Indonesian.

Ideally, the students of Play Group like playing than getting the materials from their teachers. So, the teachers have to create fun teaching. They have to use effective teaching technique to make the students interested in the class. Usually, the teachers use songs because every child likes songs. Moreover, teaching by using songs makes the students more relax.

In English teaching and learning process at Play Group, the teachers must prepare well before teaching. Teachers should choose the media and teaching techniques which are appropriate to the age of Play Group students. They must know the habits and needs of the students so that the needs for the material can be conveyed properly and smoothly. The students are learning center. Thus teachers will facilitate students to provide guidance and direction to produce a good and smart generation.

Teachers of Play Group must always be continuously reinventing them in order to update their knowledge. They should know the basic principles of teaching English. They also have to learn the habits and characteristics of students of Play Group since teaching children need more passion than teaching adults. English which is taught at the Play Group is a very simple language because children have different capabilities with adults in teaching and learning process. English is very important to be taught early because we now live in the era of digital. Recently, children are already very familiar with the gadget. Almost every day they play with gadgets. Gadgets can also provide positive and negative impacts for its users, especially children. The positive effect from gadget is there are several English language materials which can be easily downloaded. For example, stories, songs, movie etc. While the negative effect of children can be addicted to gadgets and time-consuming. Therefore, the parents' roles are much needed. 
In teaching young learners, teachers have to deliver varied and understandable material to students. Teachers should be selective in choosing the materials will be given to the students. The materials provided should be simple and based on the needs of children. In addition, it should be appropriate to their age. The ability to choose the technique of teaching by teachers is also very influential in learning.

When the writer observed in a Play Group, she explored the activity of English teaching and learning process. English language learning which is applied in that Play Group can be categorized as good since the students feel happy when they are taught by the teachers. They responded and did the instructions given by their teachers. The teachers also deliver the materials well. They sometimes use songs as a media of learning because they assume that the children like songs and the children can easily memorize songs.

In this study, the writer explored the activity of English teaching and learning at Play Group which focusing on Total Physical Response (TPR). TPR is regarded as one of the techniques that is effective in teaching children because it integrates action in the learning. Before applying the TPR to students, the writer guided the teachers about TPR. Then the writer collaborated with the teachers in applying TPR in English teaching and learning process. One of the purposes of applying TPR is to maximize English teaching and learning in the classroom and to reduce any boredom during the learning process.

In applying TPR, the writer collaborated with the teacher taught the students of Play Group. They taught the materials by using songs and actions. There were three songs. Head, shoulder, knees and toes, are you sleeping and Old Macdonald were the selected three songs. The writer and the teachers chose those songs because the songs are relating with children's life.

In the teaching and learning process, the writer and the teachers used video to support the materials. They asked the students to watch the video and did the instructions. The students were happy in enjoying the videos. They were actively participated in the activity.

Head, Shoulder, Knees and Toes discusses about parts of the body. Parts of the body considered the important materials for children. In the activity of the class, the writer and the teachers enjoyed the song. They sang together. The writer and the teachers taught about parts of the body and instructed the students to touch their parts of the body. The students were asked to sing the song and held their parts of the body. The purpose of this activity was to make the students understood about parts of the body.

Are You Sleeping was chosen by the writer and the teachers as the second song because it teaches the students to wake up earlier. In Are You Sleeping, the children were asked to be on time. In applying TPR, the writer and the teachers sang the song together. Then, they asked the students to act sleep and wake up. The writer also asked the students about wake up time. After that, the students answered the questions by showing the time to the teachers.

The writer and the teachers chose Old Macdonald as the last song because it expressed about the cattleman and his pets. They explained about pets to the students. While watching video of Old Macdonald, the writer and the teachers sang together. Then, the writer and the teachers asked the students to act like the pets. The students were also asked to imitate the sounds of the pets. 


\section{CONCLUSION AND SUGGESTION}

Based on the result of the study, the writer gives conclusion as follow: the activity of English teaching and learning in Play Group where the writer observed can be categorized well. It is proved that the students were very active in learning process. They did the teachers' instruction. In addition, the teachers enjoyed teaching their students by using Total Physical Response. When the students and the teachers enjoy in teaching and learning process, it means that the class runs well. In addition, Total Physical Response is effective to be applied in teaching English for young learners. The teachers can introduce new vocabulary when they applied Total Physical Response.

The writer of the study suggests to the teachers to use Total Physical Response. This technique can be used as one of the alternative technique in English class. It can be used not only for young learners but also adult learners.

\section{REFERENCES}

Barrow, L., \& Markman-Pithers, L. (2016). Supporting Young English Learners in the United States. Future of Children, 26(2), 159-183.

Butler, Y. G. (2015). English Language Education among Young Learners in East Asia: A Review of Current Research (2004-2014). Language Teaching, 48(3), 303-342. https://doi.org/10.1017/S0261444815000105.

Cheatham, G. A., \& Ro, Y. E. (2010). Young English Learners' Interlanguage as a Context for Language and Early Literacy Development. Young Children, 65(4), 18-23.

Coltrane, B. (2003). Working with Young English Language Learners: Some Considerations. ERIC Digest. ERIC/CLL, 4646 40th Street N. Retrieved from https://eric.ed.gov/?q=characteristics+of+young+learners\&id=ED481690.

Hafidah, A. S. (2016). Developing the Lift and Shift Game to Introduce Tenses at the Initial Stage to Children as Young Learners. Journal of Education and Practice, 7(5), 7-25.

Harrasi, A., \& Sulaiman, K. T. (2014). Using "Total Physical Response" with Young Learners in Oman. Childhood Education, 90(1), 36-42. https://doi.org/10.1080/00094056.2014.872513.

Scott, W. A., \& Ytreberg, L. (1990). Teaching English to Children. New York: Longman. 